\title{
Sensitivity pattern of drought region in Bojonegoro
}

\author{
Amrih Halil $^{1, *}$ \\ ${ }^{1}$ Department of Geography, University of Indonesia, UI Depok Campus, Depok, 16424, Indonesia
}

\begin{abstract}
Bojonegoro Regency is one of regency in East Java which affected by drought. Local Disaster Management Agency (BPBD) Bojonegoro reported 17 districts which most affected by drought in the south of Bojonegoro Regency, such as Kedewan, Sugihwaras, Kedungadem, Sukosewu, Tambakrejo, Balen, Kasiman, Ngasem, Baureno, Trucuk, Kepohbaru, Dander, Ngraho, Bubuan, Malo, Tambakrejo, and Margomulyo. This study aims to determine the region sensitivity patterns in Bojonegoro Regency in connection with drought disaster which is reviewed accordingly of physic aspect and social aspect. A physic parameter such as precipitation, the average of total precipitation during 30 years (1986-2015), type of soil for identification texture and depth of soil, and slope. While social parameter is the total population for identification of the population's water needs. The method of this study is an overlay and scoring method. The classification of region sensitivity is low, medium, high and very high. The low classification which spread in Gayam District. The medium classification which spread in Kedawen, Kasian, Malo, Padangan Purwosari, Temayang, and Sukosewu District. The high classification which spread in Tambakrejo, Kapas, Balen, Kanor, Sumberejo, Kedungadem, and Gondang District. The very high classification which spread in Margomulyo, Ngrahu, Dander, Bojonegoro, Trucuk, Baureno, Kepohbaru, Kedungadem, Gondang and Sekar District.
\end{abstract}

\section{Introduction}

Sensitivity drought regions proposed by Thornthwaite (1957) is defined as the level or degree to which regions will be affected against the drought [1]. Drought is a natural disaster that causes water crises, where water is a vital necessity for living creatures, on the other hand also provides considerable losses to human activities or activities in various fields. Kodoatie and Syarief (2010) also mentioned that one of the recent disasters that often occur in some areas in Indonesia is a drought disaster [2].

Drought, as a result of global climate change, is inseparable from the influence of El Nino Southern Oscillation (ENSO) phenomenon. ENSO as stated by Kodoatie and Syarif (2010) and Meteorology Climatology and Geophysics Agency (BMKG) (2015) is a global phenomenon in the Pacific Ocean region caused by heating and /or cooling seawater temperature, well above and /or below normal condition [3, 2].

In addition to El Nino, climate irregularities that also occur in Indonesia are Indian Ocean Dipole (IOD). Indian Ocean Dipole (IOD) is a symptom of a deviation of weather generated by the interaction between the ocean and atmospheric surfaces in the Indian Ocean region around the equator and south of Java [4]. This phenomenon is represented by differences in sea surface temperature in the western and eastern Indian Ocean [4]. In the case of the El-Nino and /or IOD phenomena, the dry season becomes longer and covers the wider drought area.
Until the end of July 2015, according to BNPB (2015) in Indonesia, there has been a water deficit of about \pm 20 billion $\mathrm{m}^{3}$ spread in Java, Bali and Nusa Tenggara island. Bojonegoro regency is one of the districts affected by drought [3]. Local Disaster Management Agency (BPBD) Bojonegoro said 17 drought-stricken sub-districts are mostly located in southern Bojonegoro, are Kedewan, Sugihwaras, Kedungadem, Sukosewu, Tambakrejo, Balen, Kasiman, Ngasem, Baureno, Trucuk, Kepohbaru, Dander, Ngraho, Bubuan, Malo, Tambakrejo, and Margomulyo. The next impact of this disaster is the clean water crisis in the region.

The purpose of this research is to know the pattern of sensitivity of Bojonegoro regency to drought disaster which is studied based on physical spec and social aspect. This research is also expected to be a consideration and reference for drought-related agencies in taking policy, overcoming and reducing losses caused by drought disaster that occurred in Bojonegoro regency.

\section{Material and method}

\subsection{Study area}

The location of the research was conducted in Bojonegoro Regency. Bojonegoro Regency is located at position $112^{\circ} 25^{\prime}-112^{\circ} 09^{\prime}$ East Longitude and $6^{\circ} 59^{\prime}$ $7^{\circ} 37^{\prime}$ South Latitude. Based on geographical position,

Corresponding author: halilamrih01@gmail.com 
Bojonegoro regency has boundaries: South of Madiun Regency, Nganjuk and Ngawi, east of Lamongan Regency, north of Tuban Regency, and west of Blora Regency of Central Java Province. Administratively Bojonegoro Regency is divided into 28 districts and 430 villages.

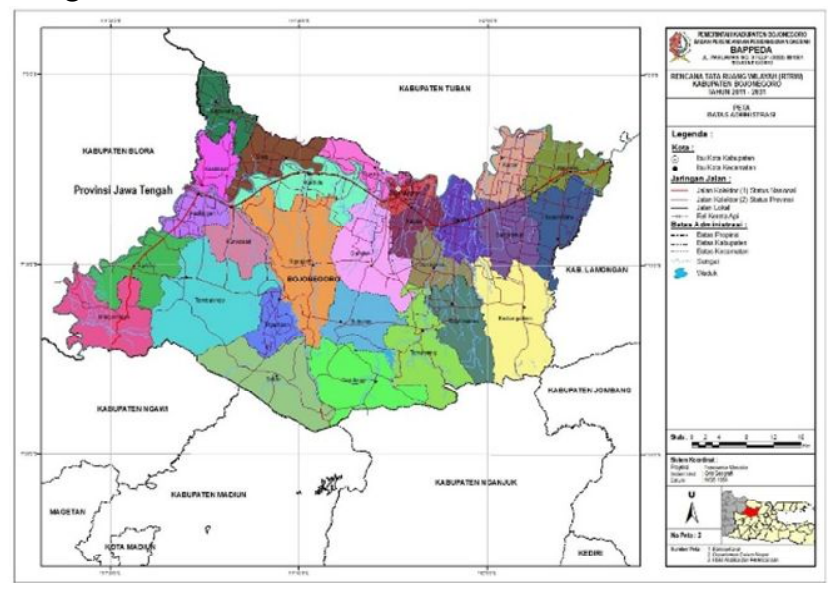

Fig. 1. Administrative map of Bojonegoro regency

Local Disaster Management Agency (BPBD) Bojonegoro said 17 drought-stricken sub-districts are mostly located in southern Bojonegoro, namely Kedewan, Sugihwaras, Kedungadem, Sukosewu, Tambakrejo, Balen, Kasiman, Ngasem, Baureno, Trucuk, Kepohbaru, Dander, Ngraho, Bubuan, Malo, Tambakrejo, and Margomulyo. The next impact of this disaster is the clean water crisis in the region.

\subsection{Research method}

This research analyze the pattern of region sensitivity to drought disaster in Bojonegoro regency. The research variables are identified based on physical and social parameters. Physical parameters that include rainfall i.e., average number of rainfall for 30 years (19862015), soil type to see the texture and soil solum , and slope. While the social parameter is the population, related to the water needs of the population.

Each parameter obtained from the secondary data that is interconnected and analysed descriptively and spatially so that can be known pattern or distribution of sensitivity of the region to drought disaster in Bojonegoro regency. Validation of the pattern is done by adjusting the region's sensitivity to drought with the disaster in Bojonegoro Regency, was conducted in the final step.

\subsection{Data collection}

The data needed during the processing and analysis to obtain the region's sensitivity pattern on drought disaster in Bojonegoro Regency is collected from related institutions. The data required in this study are as follows.

1. Monthly rainfall data from $1986-2015$ period obtained from Dinas Pengairan Bojonegoro Regency.
2. Data of soil type obtained from Balai Agroklimat Bogor.

3. The slope of the slope obtained from the DEM data processing.

4. Data on the population of 2016 obtained from the Central Bureau of Statistics of Bojonegoro Regency.

\subsection{Tabular data processing}

\subsubsection{Rainfall data}

Arranging monthly rainfall data that has been obtained based on observer station rainfall for 30 years (19862015), than calculating the average number of rainfall for 30 years (1986-2015).

\subsubsection{Population data}

Population data obtained is the data of population each sub-district in Bojonegoro Regency which processing by using Microsoft Excel with a formula to determine the amount of water used in each district in Bojonegoro Regency.

\subsubsection{Spatial data processing}

Spatial data processing using ArcGIS 10.1 software. For the average data of 30 years of rainfall (1986-2015) that has been processed by tabular then spatially processed by IDW Interpolation method using Spatial Analysis Tools on arc toolbox on Interpolated Raster menu. The IDW method is the method used to connect points of equal value by considering other points of different value and able to estimate the value of an area based on the points. Meanwhile, for the processing of spatial data of the population that is by entering the population data in attribute table the administrative map of Bojonegoro Regency each sub-district.

\subsection{Data analysis}

Data that has been processed in quantitative and spatial subsequently analyzed further to be able to answer research questions. To be able to answer the research question "How is the pattern of sensitivity of Bojonegoro region to drought disaster?" Used descriptive and spatial analysis. Spatial analysis is used to analyze the pattern distribution level of sensitivity to drought in Bojonegoro Regency, while the descriptive analysis is used to explain the results of spatial analysis such as what areas are sensitive to drought in Bojonegoro Regency.

\section{Result and discussion}

Each variable divided into four classifications and scoring as follows. 


\subsection{Average amount of rainfall}

The average amount of rainfall is small will trigger the occurrence of drought disaster so that the sensitivity of the region to drought is higher.

Table 1. Classification and scoring of rainfall

\begin{tabular}{|c|c|}
\hline $\begin{array}{c}\text { Average amount of rainfall } \\
\text { (mm/year) }\end{array}$ & Scoring \\
\hline$>2500$ & 1 \\
\hline $2000-2500$ & 2 \\
\hline $1500-2000$ & 3 \\
\hline $0-1500$ & 4 \\
\hline
\end{tabular}

\subsection{Soil solum}

Deep soil solum contains more water (Susanto, 2014). Therefore, the shallower the soil solum, the more sensitive its territory to drought.

Table 2. Classification and scoring of soil solum

\begin{tabular}{|c|c|c|}
\hline $\begin{array}{c}\text { Soil Solum } \\
(\mathbf{c m})\end{array}$ & Classification & Scoring \\
\hline$>120$ & Very Depth & 1 \\
\hline $90-120$ & Depth & 2 \\
\hline $50-90$ & Medium & 3 \\
\hline $0-50$ & Low & 4 \\
\hline
\end{tabular}

\subsection{Soil texture}

Ground with a coarse texture will easily escape the water because it has a lot of pore space between the soil particles, so that the water contained in the soil will fewer in number and become infertile, while the soil with a fine texture will take longer in binding water because the soil particles are very small and fill the entire space on the pores of the soil, so the water contained therein (Susanto, 2014).

Table 3. Classification and scoring of soil texture

\begin{tabular}{|c|c|c|}
\hline $\begin{array}{c}\text { Soil } \\
\text { Texture }\end{array}$ & Classification & Scoring \\
\hline Soft & Clay, sandy clay, silty clay & 1 \\
\hline Medium & Loamy dust, dust, loam & 2 \\
\hline Coarse & Sandy loam & 3 \\
\hline Very Coarse & Sand, loamy sand & 4 \\
\hline
\end{tabular}

\subsection{Slope}

The slope in an area is very influential on the amount of water contained in the soil. The steeper the slope can be ascertained that the area has fewer water reserves when compared to areas with flat slope conditions (Susanto, 2014). Therefore, the steeper the slope the higher the sensitivity of the region against drought disaster.
Table 4. Classification and scoring of slope

\begin{tabular}{|c|c|c|}
\hline Slope (\%) & Classification & Scoring \\
\hline $0-8$ & Flat & 1 \\
\hline $8-15$ & Slope slightly & 2 \\
\hline $15-25$ & Steep & 3 \\
\hline$>25$ & Very Steep & 4 \\
\hline
\end{tabular}

\subsection{Total population}

The higher of the total population in a region will be more water needs. Therefore, if water demand is higher, then they are likely to be sensitive to drought.

Table 5. Classification and scoring of total population

\begin{tabular}{|c|c|}
\hline $\begin{array}{c}\text { Total Population } \\
\text { (People) }\end{array}$ & Scoring \\
\hline $0-25000$ & 1 \\
\hline $25000-50000$ & 2 \\
\hline $50000-75000$ & 3 \\
\hline$>75000$ & 4 \\
\hline
\end{tabular}

\subsection{Classification level of drought sensitivity}

Each variable sensitivity level of dryness has been awarded a score or value or scoring overlay process is then carried out using ArcGIS 10.1 software by combining each variable and summing each score of each of these variables to determine the level of sensitivity to drought.

The results of the sensitivity level classification in Bojonegoro Regency towards drought divided into four classes: levels of low, moderate, high and very high sensitivity.

\subsection{Rainfall distribution}

The Pattern of distribution of an average number of rainfall amounts of 30 years from 1986 to 2015 is divided into 4 classes, namely $0-1500 \mathrm{~mm} /$ year, $1500-$ $2000 \mathrm{~mm} /$ year, $2000-2500 \mathrm{~mm} /$ year and $>2500 \mathrm{~mm} /$ year. The pattern of distribution of the average number of rainfall 30 years period 1986-2015 is dominated by the class of $1500-2000 \mathrm{~mm} /$ year spread from north to south and east of Bojonegoro Regency.

\subsection{Soil solum distribution}

The soil solum distribution pattern is divided into 4 classes, i.e 0-50 cm, 50-90 cm, 90-120 cm, > $120 \mathrm{~cm}$. Solar soil distribution pattern $>120 \mathrm{~cm}$ spread in the north of Bojonegoro Regency, 90-120 cm solum soil spread in east and west of Bojonegoro Regency, 50-90 $\mathrm{cm}$ solum of land spread in southeast and southwest of Bojonegoro Regency. 0-50 ground solum spread over central and southern Bojonegoro Regency. 


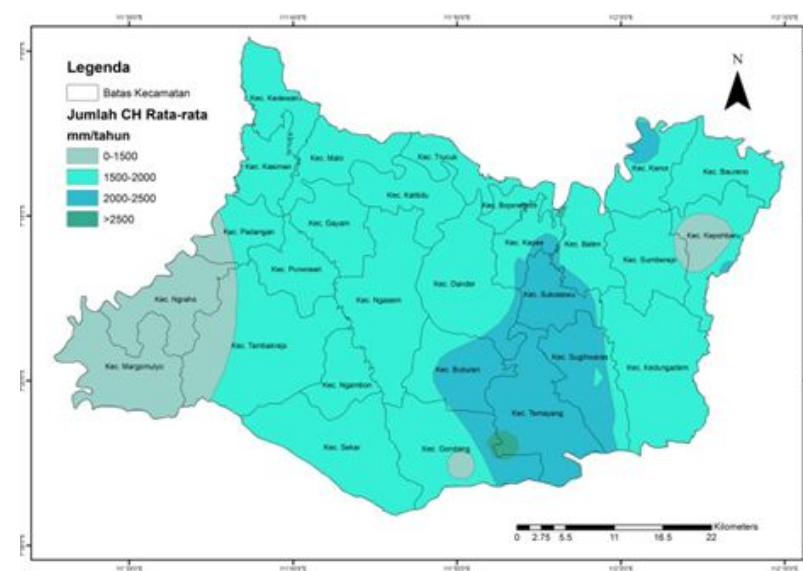

Fig. 2. Map of average number of rainfall amount of 30 years (1986-2015) in Bojonegoro regency

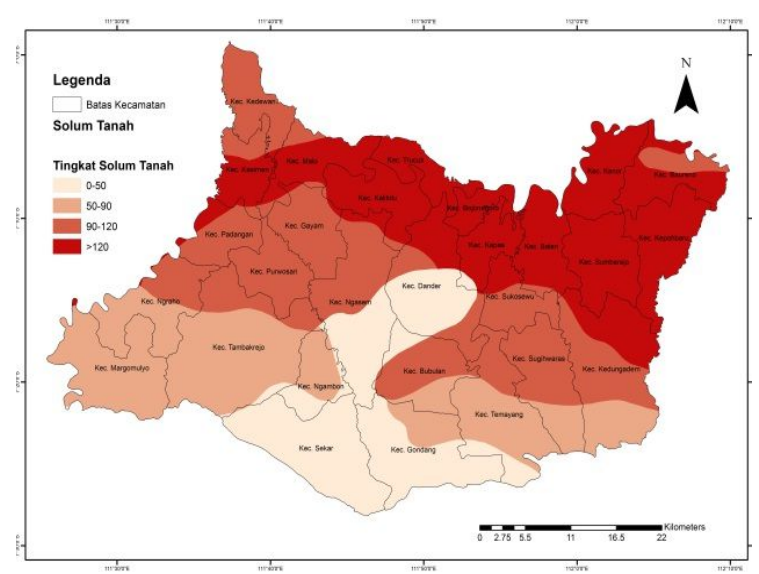

Fig. 3. Map of soil solum in Bojonegoro regency

\subsection{Soil texture distribution}

The pattern of the distribution of soil texture is divided into 4 classes: smooth, medium, slightly coarse and coarse. The distribution pattern of fine soil texture bar in northern Bojonegoro, soil texture was scattered in the east and west of Bojonegoro, soil texture rather coarse scattered in the southeast and southwest Bojonegoro. Rough earth texture spread in center and south of Bojonegoro Regency.

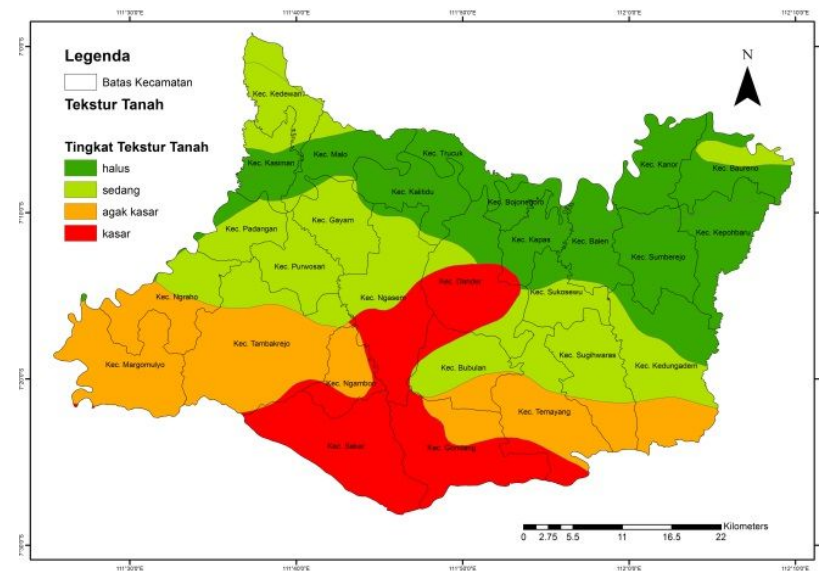

Fig. 4. Map of soil texture in Bojonegoro regency

\subsection{Slope distribution}

The slope distribution pattern is divided into 4 classes, i.e $0-8 \%, 8-15 \%, 15-25 \%$ and $>25 \%$. Spreading pattern of slope $0-8 \%$ spread in, north, west to east Bojonegoro, slope $8-15 \%$ spread in the southwest to southeast Bojonegoro, slope $15-25 \%$ and $>25 \%$ slope spread in south part of Bojonegoro Regency.

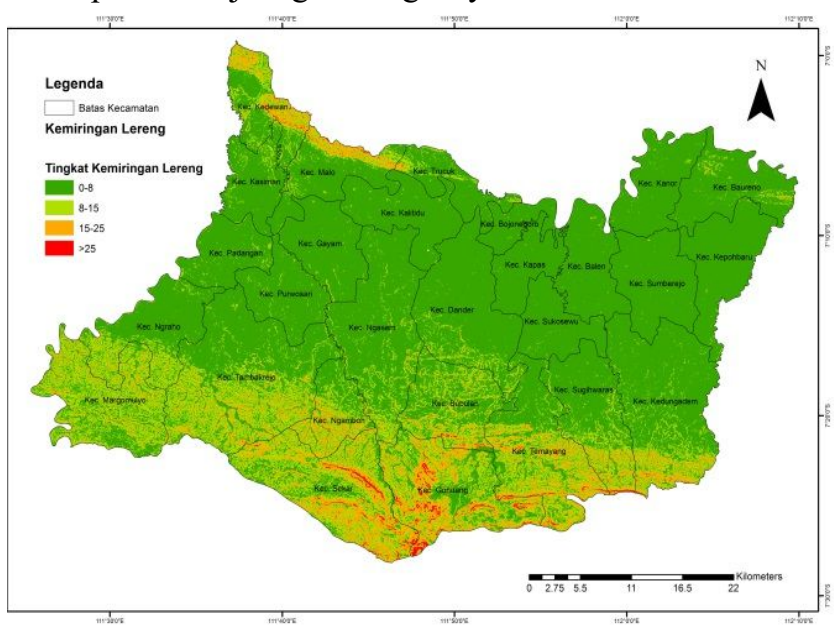

Fig. 5. Map of slope in Bojonegoro regency

Table 6. Classification and scoring of sensitivity level

\begin{tabular}{|c|c|c|c|c|c|}
\hline $\begin{array}{c}\text { Sensitivity } \\
\text { Level }\end{array}$ & $\begin{array}{c}\text { Rainfall } \\
(\mathbf{m m} / \mathbf{y} \text { ear) }\end{array}$ & Soil Texture & $\begin{array}{c}\text { Soil } \\
\text { Solum } \\
\mathbf{( c m )}\end{array}$ & $\begin{array}{c}\text { Total Population } \\
\text { (People) }\end{array}$ & $\begin{array}{c}\text { Slope } \\
\text { (\%) }\end{array}$ \\
\hline Low & $>2500$ & Soft & $>120$ & $0-25000$ & $0-8$ \\
\hline Medium & $2000-2500$ & Medium & $90-120$ & $25000-50000$ & $8-15$ \\
\hline High & $1500-2000$ & Coarse & $50-90$ & $50000-75000$ & $15-25$ \\
\hline Very High & $0-1500$ & Very Coarse & $0-50$ & $>75000$ & $>25$ \\
\hline
\end{tabular}




\subsection{Total population distribution}

The distribution pattern of population 0-250000 people spread in west and south of Bojonegoro Regency, the population of $25000-50000$ people spread in the northwest and southeast Bojonegoro Regency, the population 50000-75000 people spread in the east and central Bojonegoro regency and the population $>75000$ people spread in the center and southeast of Bojonegoro regency.

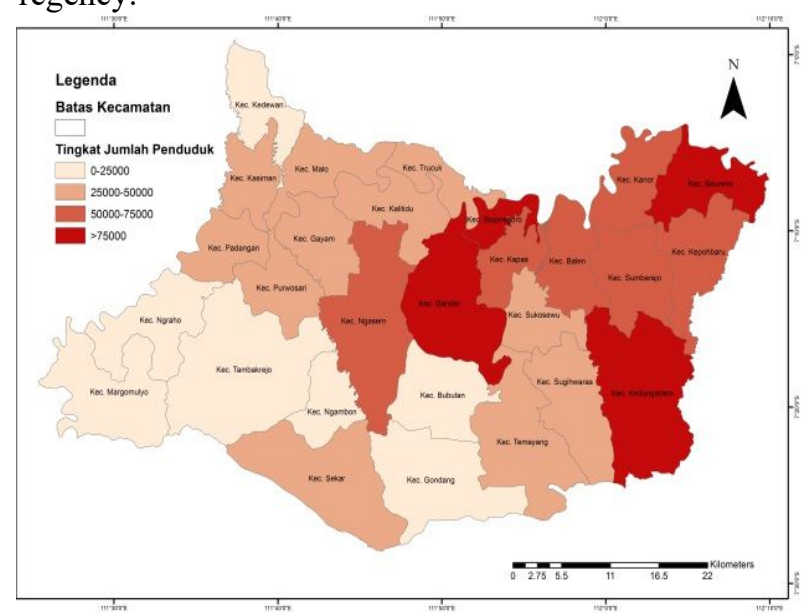

Fig. 6. Map of total population in Bojonegoro regency.

\subsection{Sensitivity pattern of drought region}

The drought sensitivity pattern is divided into four classes, i.e low, medium, high and very high. Low sensitivity level is only spread in one district in Bojonegoro Regency, Gayam District in the northern and eastern sub-districts. The low sensitivity level is only 6 , $921 \mathrm{~km} 2(0.3 \%$ of the total area of Bojonegoro Regency). The medium level of sensitivity was almost scattered throughout Bojonegoro regency. Mostly in the northwest and southeast Bojonegoro. The largest subdistricts have moderate sensitivity levels among them Kedawen, Kasian, Malo, Padangan Purwosari, Temayang, and Sukosewu. The medium sensitivity level of $1385,928 \mathrm{~km} 2(60.03 \%$ of the total area of Bojonegoro Regency). of these variables to determine the level of sensitivity to drought.

High sensitivity levels are scattered in the eastern and southwestern parts of Bojonegoro Regency. The subdistrict which has high sensitivity levels include Tambakrejo, Kapas, Balen, Kanor, Sumberejo, Kedungadem, and Gondang. The high sensitivity level of $357,594 \mathrm{~km} 2 \quad(15.5 \%$ of total area of Bojonegoro Regency). Very high sensitivity levels are scattered in the west, central, northern, southern and eastern Bojonegoro Regency. The sub-district that have very high sensitivity include Margomulyo, Ngrahu, Dander, Bojonegoro, Trucuk, Baureno, Kepohbaru, Kedungadem, Gondang and Sekar. Very high sensitivity level $556,616 \mathrm{~km} 2(24.17 \%$ of the total area of Bojonegoro Regency).

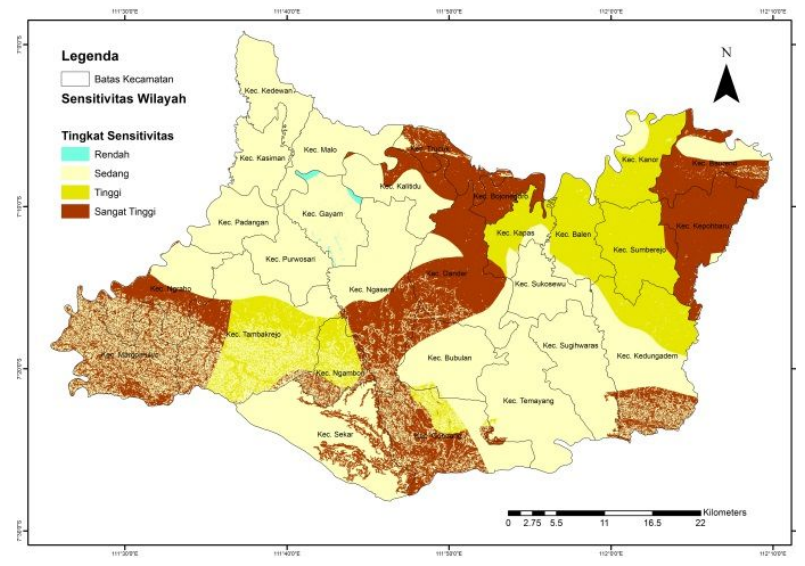

Fig. 7. Sensitivity pattern of drought region in Bojonegoro regency.

Acknowledgements are presented to the lecturer staff Department of Geography FMIPA University of Indonesia who has provided knowledge and motivation all this time. The government agencies of Bojonegoro Regency and the respondents of the research area has provided data for research purposes. Parents and friends who always give support and motivation.

\section{References}

1. Thornthwaite, C.W. and Mather, J.R..Instruction and Tables for Computing Potential Evapotranspiration and the Water Balance. Drexel Institute of Technology. Laboratory of Climatology. New Jersey, USA (1957)

2. Kodoatie, R. J. \&R. Sjarif. Water Management System. Yogyakarta: Andi (2010)

3. Meteorology, Climatology, and Geophysics Agency. Monitoring Indonesia's Consecutive Rain-Free Day Dasarian III Updated 30 November 2015. Malang: Klimatologi Karangploso Station (2015)

4. Iskandar, I. There are "Two Poles" in the Indian Ocean. Taken from fisik@net, main reference: http://www.fisikanet.lipi.go.id/ (2008)

5. Meteorology, Climatology, and Geophysics Agency. Monitoring Consecutive Rainy Day Without Rain Update 31 August 2015. Malang: Klimatologi Karangploso Station (2015)

6. BNPB. Head Regulation of the National Disaster Management Agency Number 02 of 2012 concerning General Guidelines for Disaster Risk Assessment. Jakarta: National Disaster Management Agency (2012)

7. Rohmah, F. The Effect of Climate Deviations on Food Security in Kebumen District, Depok. Thesis of Geology Department, Faculty of Mathematic and Natural Science, Indonesia University (2014)

8. Thornthwaite, C.W. and Mather, J.R..Instruction and Tables for Computing Potential Evapotranspiration and the Water Balance. Drexel Institute of Technology. Laboratory of Climatology. New Jersey, USA (1957) 
9. Tjasyono, Bayong. General Climatology. Bandung: Institut Tekhnologi Bandung (1999)

10. Bonjornegoro Statistics Center. Bonjornegoro in the Number 2016. BPS:Bojonegoro (2017)

11. Susanto. Drought Disaster Risk in Indonesia in the FGD Map of Drought Exposure. Meteorology, Climatology, and Geophysics Agency. Jakarta. (2014)

12. Meteorology, Climatology, and Geophysics Agency. Drought-prone Atlas of Banten. BMKG's Center for Agroclimate Climate and Maritime Climate. Jakarta (2010)

13. Olivia, Lingga. Making Drought-prone Maps in Bali, Thesis of Climatology Program. School of Meteorology, Climatology and Geophysics (2014) 